Матеріали Всеукраїнської науково-практичної конференції «Актуальні питання діагностики, лікування, раціональної фармакотерапії, диспансеризації та реабілітації в практичі сімейного лікаря"

DOI

\title{
КЛІНІЧНІ ПРОЯВИ ВЕГЕТАТИВНОГО ДИСБАЛАНСУ У КЛІМАКТЕРИЧНОМУ ПЕРІОДІ ТА МОЖЛИВОСТІ ЇХ КОРЕКЦІї
}

๑В. М. Ждан, І. П. Катеренчук

ВДНзу «Українська медична стоматологічна академія»

Актуальність проблеми. Вегетативні порушення, які виявляють майже у 80 \% жінок, $є$ найбільш ранніми проявами клімактеричного синдрому. Кардіальна і церебральна симптоматика значно погіршує якість життя і $\epsilon$ передумовою тяжких ускладнень, які погіршують якість життя та зменшують його тривалість.

Мета дослідження - оцінити перебіг клімактеричного періоду у жінок з клінічними проявами вегетативного дисбалансу і розробити спосіб їх корекції засобом, який має комплексну антиоксидантну, мембраностабілізувальну, нейропротекторну та антиішемічну дію.

Дизайн дослідження. Проведено комплексне дослідження ефективності Мексикору у 38 жінок 3 діагностованими кардіальними та церебральними проявами клімактеричного синдрому. Контрольну групу склали 35 жінок, які перебува- ли на гормонозамісній терапії. Мексикор призначали по 100 мг 3 рази на день, при необхідності дозу збільшували до 200 мг 3 рази на день. Тривалість лікування 1-2 місяці.

Пацієнтам проводили стандартне загальноклінічне обстеження, ЕКГ, ехокардіографічне обстеження, холтерівське моніторування ЕКГ, фазаграфію. Оцінку якості життя, наявність тривожності та депресії оцінювали за спеціальними опитувальниками.

Результати проведеного дослідження засвідчили, що додаткове призначення Мексикору забезпечувало статистично достовірне зменшення клінічних проявів кардіального синдрому. Одночасно відзначався позитивний вплив цього препарату на психоемоційні прояви патологічного клімактерію, які суттєво погіршували якість життя пацієнток. 